\title{
Los pergaminos de la memoria. El genocidio indígena de la Patagonia austral (1880-1920) en la obra de los poetas magallánicos Juan Pablo Riveros, Pavel Oyarzún y Christian Formoso
}

Lorena López Torres, Santiago: Cuarto propio, 2017. Pp.400. ISBN 978956260964-7

¿Qué puede hacer el arte frente a un genocidio? No es documentarlo, porque el arte va más allá de la historia y del periodismo. Es volver los muertos a la vida. El libro de Lorena López, Los pergaminos de la memoria (2017) analiza la literatura magallánica desde ese acto literario de darle vida a los muertos que vivieron en la Patagonia y sus alrededores. Su tesis es que la poesía del extremo sur del mundo dialoga con el genocidio de los pueblos indígenas selk'nam y kawésqar fundamentalmente. Para ello elige un corpus de tres poetas: Juan Pablo Riveros, Pavel Oyarzún y Christian Formoso, que conforman tres promociones de escritores y por ello permiten recorrer la historia desde la década de 1980 al periodo del 2000.

La categoría teórica central del libro es el genocidio, concepto del cual hace una genealogía, siguiendo un estilo foucoultiano de perspectiva que indaga sobre los orígenes del concepto y sus usos disciplinarios en el área de la jurisprudencia. A partir de allí, marca el inicio del concepto en 1933 como una consecuencia de las masacres causadas por la I Guerra Mundial a los sirios, griegos y armenios. El uso de la palabra genocidio lo adjudica al jurista judío polaco Raphael Lenkin, con quien la Dra. López comparte un punto de vista y que la llevará a alejarse del concepto de etnocidio. Las acciones que permitirían hablar de genocidio son cinco: 1)“Matanza de miembros de un grupo; 2) Lesión a la integridad física o mental de los miembros de un grupo; 3) Sometimiento del grupo a condiciones de existencia que hayan de acarrear su destrucción física, total o parcial; 4) Medidas destinadas a impedir los nacimientos en el seno del grupo; 5) Traslado por fuerza de niños del grupo a otro grupo" (p. 33).

Con estas acciones en mente, la Dra. López relaciona el genocidio, en la Patagonia, con los discursos intelectuales que conciben al indígena como un salvaje, lo que permitió “expropiar los territorios” (p. 58); con las teorías que lo concebían sin cultura, pero que podía ser educado y era necesario ubicarlo en misiones religiosas para ello, como isla Dawson; para finalizar con la idea del indigenismo ecológico que impulsa la creación de la Corporación Nacional de Desarrollo Indígena, CONADI, en 1993, por el gobierno de Patricio Aylwin. Junto con este posicionamiento de las ideas, la Dra. López recurre a datos históricos proporcionados por su lectura acuciosa de fuentes reconocidas sobre esta área. 
Sobre cómo la literatura magallánica se ha acercado al tema de la descripción del genocidio, la profesora López sistematiza el recorrido que han hecho los historiadores y críticos Mateo Martinic, Osvaldo Wegman, Ernesto Livacic y Pavel Oyarzún, quienes identifican una línea de escritura donde se destaca la vida rural del migrante europeo, "la conflictiva adaptación del colono a su situación de extranjero en una tierra nueva” (p. 138) y la "presencia de paisajes y personajes reconocibles" (p. 137). En ese momento literario, "el universo indígena y el genocidio constituyen preocupaciones más bien periféricas” (p. 139). En esa periferia y sólo con algunos textos relativos a los indígenas están Enrique Campos Menéndez y Enrique Wegmann. Pero son Francisco Coloane y Osvaldo Wegmann, quienes van a producir relatos donde el indígena es tratado más allá de la representación vernacular. Cierra esta línea de escritura Eugenio Mimica quien marcará el fin de ese estilo literario vernacular para recrear al indígena en los años 70 .

Paralelamente a la narrativa vernacular, en poesía, se impone "un arquetipo de poeta, ocupado de la exaltación paisajista, que canta al estoicismo y tesón del pionero" (p. 159), tópico que domina la lírica hasta la aparición de Aristóteles España quien poetiza la prisión y tortura que sufrió en isla Dawson a inicios de la dictadura militar. A partir de allí y con un estilo más neovanguardista se desarrollan las escrituras de Juan Pablo Riveros, Astrid Fugellie, María Cristina Ursic, Maribel Valle, Juan Magal, Juan Garay, Pavel Oyarzún y Christian Formoso. Serán ellos los que se preocuparán de encontrar una manera de darle forma artística al genocidio indígena.

La resolución de la escena estética para describir el genocidio lleva a los poetas a pensar en la fotografía. Esta es la segunda tesis central del libro de la profesora López. Si la primera fue que la poesía magallánica se relaciona con el genocidio, echándole a perder la fiesta a los estancieros; la segunda, será que esta poesía tiene una relación intermedial con las fotografías que se conservan del genocidio. La autora de este libro nos ofrece una completa documentación acerca de quiénes y en qué contexto tomaron fotografías del exterminio. La autora muestra sus simpatías con las fotografías tomadas por el etnógrafo y sacerdote de la Orden del Verbo Divino, Martín Gusinde durante su estadía con los selk'nam entre 1918 y 1924 y toma distancia con las fotografías tomadas por el propio exterminador, el ingeniero rumano Iulius Popper, y su comitiva.

El primer poeta analizado de forma bellísima es Juan Pablo Riveros el que construye, en el libro De la tierra sin fuegos (1986) un poema donde se escuchan la mayoría de las voces de principios de siglo XX. El poema incorpora "las voces de los indígenas y de sus dioses; de los estancieros José Nogueira y Moritz Braun y de sus colaboradores Leoncio Rodríguez y Peter Mc Clelland; de los defensores de los indígenas, Martin Gusinde y el arqueólogo Joseph Emperaire" (p. 192). Para la autora, la voz poética central se ubica empáticamente en el lugar que ocuparon Gusinde y Emperaire. Como ellos, la voz poética se empapa de los mitos ancestrales "Temaukel y Ayayema; de las ritualidades y tradiciones ceremoniales, "Hain I" y "Hain II"; del conocimiento del indígena sobre la naturaleza, "Shukaku I" y "Mar yámana”; y 
de la relación que tiene con el mundo animal, "Carrcai, el Carrancho” y El Guanaco" (p. 200). La voz de Gusinde describe esos saberes y denuncia el trasporte obligado de los selknam a isla Dawson iniciado en 1905. La voz y las fotografías de Gusinde incorporadas al poemario son centrales porque es la subjetividad que aprecia a los indígenas como gente con cultura y desde ahí se opone al genocidio. Para matar hay que primero desvalorizar. Gusinde valoriza y salva.

La autora destaca que el poemario de Riveros le otorga voz también a Emperaire, el etnógrafo francés que viaja a la Patagonia por encargo del Museo del Hombre de París. En 1946 llega a Magallanes acompañado de su esposa y es testigo del ocaso, la pobreza, y el alcoholismo a que son sometidos estos pueblos. La voz de Emperaire en el poemario acusa a los religiosos de ignorar por completo el aprendizaje de la lengua nativa como herramienta para comunicarse con los fueguinos. A través de las voces de Gusinde y Emperaire, Riveros relata el genocidio que contempló, desde la supresión del seno de las mujeres, para evitar la descendencia; la guerra bacteriológica indirecta de prohibirles su comida y vestidos, obligándolos a usar una ropa usada y contaminada para ellos; hasta su traslado obligado a la isla Dawson.

El segundo poeta profundamente analizado es Pavel Oyarzún, quien construye en La cacería (1989), siguiendo a la Dra. López, una subjetividad que interroga las fotografías del genocidio. La segunda edición modificada (1999) cuenta con dos textos metatextuales, "No hay otro Dios" y "Austronauta", considerado por la autora un manifiesto del poeta. En ellos destaca el interés por posicionar los significantes ancestrales, como Karukinka, nombre primero de Tierra del Fuego y situar el momento del exterminio tipo cacería en la última década del siglo XIX. El poemario presenta bajo la figura de la cacería, deporte reinal y colonial, el genocidio indígena.

La voz del poemario de Oyarzún, desde el análisis de la Dra. López, corresponde al que mira el horroroso safari desde su contemporaneidad e increpa el pasado invitando a que los humillados levanten la vista (p. 292). Los sujetos mirados, los (e)spectrum, de la fotografía, transitan desde el destello de luz de la imagen verbal escrita por el espectador (p. 297), para ser vistos en su fisicidad. Oyarzún describe esos cuerpos que ya no pueden estar en pie, por la tos convulsiva o el chancro, enfermedad que produce heridas y úlceras en la zona genital. El poeta logra ver, a través de la foto, el cuerpo obligado a desnudarse para la pose, o golpeado con una vara para que suba a un barco que lo llevará a otro mundo. El poeta detiene el genocidio cuando ya no tan solo ve a la víctima en las fotografías del horror repetidas una y otra vez, sino que ve a la bestia agazapada en el golpe que hace el maltrato.

El último poeta analizado es Christian Formoso, quien elabora en El cementerio más hermoso de Chile (2008), un texto donde los muertos hablan desde las tumbas del cementerio Sara Braun de Punta Arenas. Esos muertos abarcan múltiples épocas históricas, desde antes del relato de Pigaffeta hasta la época actual de las poblaciones alejadas del centro que pueblan Punta Arenas. Los muertos le reclaman a Pigaffeta, el amanuense de Hernardo de Magallanes 
la forma cómo los relató, pero el escribiente defiende su esfuerzo por dar cuenta de los primeros sepulcros correspondientes a la rebelión entre los propios marineros. Formoso da vuelta el discurso de los indígenas como caníbales y representa a los marineros de Sarmiento de Gamboa como caníbales entre ellos, desesperados tras la partida de su superior para conseguir nuevas naves.

El modelo discursivo con que hablan varios de los muertos corresponde a lo que la doctorada por la Freie Universitët de Berlín llama tableau vivant, haciendo referencia a las hablas de los presentadores de zoológicos humanos, reality show o escena teatral de carnaval que emplea Formoso para introducir los procedimientos de la humillación del pasado y del presente. Tanto en los tablaeu vivant como en los reality la fuerza motora que impulsa el espectáculo es ver el esfuerzo de sobrevivir, de permanecer de pie de los participantes.

La escena teatral de la pelea entre pioneros adinerados y los obreros pauperizados imaginada y poetizada por Formoso, pone en cuestión la posibilidad de una lectura de lucha de clases actual, pues representa a un público que ríe ante tal evento, pues ya no se identifica con el obrero. La voz toma distancia de esa burla ante el asesinato de los obreros de los frigoríficos de Puerto Natales y deja en suspenso nuestra capacidad de conmoción actual.

Tanto en Formoso, como en los dos poetas anteriores, la Dra. López da cuenta de un profundo entramado intertextual donde los poetas citan a otros escritores magallánicos y citan otras escrituras sobre el territorio, conformando un grupo de intelectuales que dialoga entre sí y con su tradición. La autora destaca esa conversación literaria, bajo el entendido que en el diálogo está la fuerza capaz de impedir todo genocidio.

\author{
Magda Sepùlveda ERIZ \\ Pontificia Universidad Católica de Chile \\ MSEPULVU@UC.CL
}

